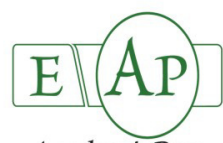

AcademicPres

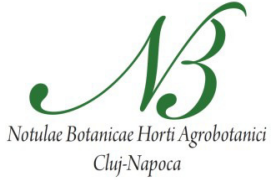

Original Article

\title{
Morphological and Molecular Characterization of Major Quince Cultivars from Turkey
}

\author{
Hasan PINAR ${ }^{1}$, Suat KAYMAK ${ }^{2}$, Serif OZONGUN ${ }^{3}$, Aydın UZUN ${ }^{1}$, Mustafa UNLU ${ }^{4}$, \\ Mustafa BIRCAN ${ }^{4}$, Sezai ERCISLI ${ }^{5 *}$, Emine ORHAN ${ }^{6}$ \\ 'ErciyesUniversitySeyraniAgriculturalFacultyDepartmentofHorticulture,38400Develi-Kayseri,Turkey; hasanpinar@erciyesedu.tr; aydinuzun@erciyesedu.tr \\ 2DirectorateofPlantProtection Central ResearchInstitute,06172Ankara,Turkey; suatkaymak@zmmae.gov.tr \\ ${ }^{3}$ Fruit Research Institute, 32500Egirdir-Isparta, Turkey;sozongun@marim.gov.tr \\ 4AlataHorticultureResearchInstitute,33740Erdemli-Mersin,Turkey;unlu.mustafa@gthb.gov.tr; bircanmustafa@gthb.gov.tr \\ 5AtaturkUniversity Agricultural Faculty, Department of Horticulture, 25240Erzurum; Turkey; sercisli@atauniedu.tr( (corresponding author) \\ ${ }^{6}$ AtaturkUniversity Agricultural Faculty,Department of Agricultural Biotechnology,25240Erzumum; Turkey; corhan@atauniedu.tr
}

\begin{abstract}
Quince (Cydonia oblonga Mill.) belongs to the Rosaceae family is native to south-eastern Europa and Asia Minor. It is generally used for table consumption and processed into jam, jelly and marmalade. It is also used as dwarfing rootstock for pear cultivars. In the present study, fruit characteristics and genetic diversity of 17 quince cultivars from Turkey were investigated. For fruit characteristics, 'Bardacik' had the highest fruit weight. The highest SSC/Acidity ratio were obtained from 'Osmancik'. There was high level of variation in fruit characteristics among cultivars. In molecular analysis, totally 133 bands were obtained from 23 sequence-related amplified polymorphism (SRAP) primer combinations and 67 of them were polymorphic. Genetic similarity of 17 cultivars was between 0.78 and 1.00 . Two cultivars ('Sekergevrek' and '32S04') were found to be more distinct from the other cultivars genetically. This study showed that there was low level of genetic variation most of quince cultivars grown in Turkey. SRAP markers firstly used in quince with this study indicating that it can be used for characterization and diversity analysis of quince.
\end{abstract}

Keywords: Cydonia oblonga, fruit properties, molecular markers, SRAP

\section{Introduction}

Horticulture plants have been using by people for food, either as edible products, or for culinary ingredients, for medicinal use or ornamental and aesthetic purposes for a century. They are genetically very diverse group and play a major role in modern society end economy. Edible plants are an important component of traditional food, but are also central to healthy diets of modern urban population (Bajpai et al., 2014; Feng et al., 2014; Ruttanapraset et al., 2014).

Quince (Cydonia oblonga Mill.) is used mainly for food industry to obtain jam, jelly and marmalade and dwarfing rootstock for pear cultivars as well (Rodger and Campbell, 2002). Quinces a good source of minerals like potassium, phosphorus and calcium. Especially, processed products like jam and jelly were prepared and assessed for their nutritive quality and acceptability for the food industry (Westwood, 1993; Sharma et al., 2011).

Turkey is the most important producer of quince in the world with an annual production of nearly 135.000 tons (FAO, 2012). The most desirable cultivars grown in Turkey are 'Limon', 'Ekmek' and 'Eşme'. In Turkey, many quince cultivars have been cultivated for their edible fruits for a long time. Besides, some quince cultivars are used for table consumption due to their soft flesh, but others are used mostly in industry for jam and marmalade processing. Selected types of quince can be used as rootstock for pears, inducing dwarf growth, but not completely frost resistance (Ercisli, 2004). It is growing in all regions but mostly widespread in north and west of the Turkey and its regional distribution closely corresponds with pear(Sykes, 1972).

Determination of morphological and genetic diversity between cultivars is important for conservation and to arrange future breeding programs in plants (Erayman et al., 2014; Kacar et al., 2014). Morphological characters may be influenced by environmental conditions whereas genetic characters is not influenced. Using both of them for germplasm characterization can give more information about germplasm. Molecular markers provide discriminatory information, and they are commonly used for germplasm characterization for fruit species in addition to pomological traits (Dumanoglu et al., 2009). Some of molecular marker systems have been used to determine genetic relationships among cultivars and species in quince. For example, quince cultivars and their clones was evaluated by molecular markers including randomly amplified polymorphic DNA (RAPD) (Bayazit et al., 2011) and simple sequence repeats (SSR) (Yamamoto et al., 2004; Dumanoglu et al., 2009; Halasz et al., 2009). 
Sequence-related amplified polymorphism (SRAP) was used firstly in Brassica for marker development and mapping ( $\mathrm{Li}$ and Quiros, 2001). Then this system have been used in many crops including cucurbits (Ferriol et al., 2003), buffalograsses (Gulsen et al, 2005), citrus (Uzun et al., 2009) and apricot (Uzun et al., 2010) for genetic diversity and fingerprinting studies. SRAP markers are a simple and also efficient system that can be adapted for a variety of purposes in different crops, including map construction, gene taging, genomic and $\mathrm{cDNA}$ fingerprinting, and map based cloning. Also some advantages of this system were reported; simplicity, reasonable throughput rate, allows easy isolation of bands for sequencing and, most importantly, it targets open reading frame (ORFs) (Li and Quiros, 2001). Up to now there is no report used SRAP markers to identification of quince germplasm.

The objective of this study was to determine variations of some agronomical traits and determine genetic diversity and reletionships using SRAP marker system in some quinces cultivars grown in Turkey.

\section{Materials and Methods}

\section{Biological material and site description}

This study was conducted with 17 quince cultivars, which preserved in Quince Genetic Resources Plantation by Egirdir Horticulture Research Station, Isparta, southwest of Turkey (Table 1). The materials were collected from different parts of Turkey previously. Most of them are the cultivars for fresh consumption. All cultivars were grafted on the 'Quince A' rootstock and trees were eight years old. The trees were managed according to standard local commercial practices, pruned annually, and watered, as needed using a drip irrigation system. Fertilization was managed based on soil and leaf analysis. Herbicides were used for weed control. Pest populations and disease were kept under control a recommended protection management program.

\section{Experimental procedures and morphological analysis}

Twenty-five fruits per cultivars were collected in October commercial harvesting season of quince in Turkey. All fruit samples were assessed for fruit weight $(\mathrm{g})$, fruit length $(\mathrm{mm})$, fruit width $(\mathrm{mm})$, fruit firmness (kg), SSC (soluble solid content, \%), pH, acidity (\%), SSC/Acidity for 2 years (2010-2011).

\section{Molecular analysis}

For molecular analysis, genomic DNA was extracted from young leaves of 17 accessions by the CTAB method as described by Doyle and Doyle (1990). DNA concentration was measured with a microplate spectrophotometer (BioTek Instruments, Inc, Vinooski, USA), and $10 \mathrm{ng} / \mu \mathrm{LDNA}$ templates were made using TE $(10 \mathrm{mM}$ Tris- $\mathrm{HCl}, 0.1 \mathrm{mM}$ EDTA, $\mathrm{pH}$ 8.0). A total 23 SRAP primer combinations were used for all quince cultivars (Table 2). PCR reaction components and PCR cycling parameters were performed as described by Uzun et al. (2009). PCR products were separated on $2 \%$ agarose gel in $1 \times$ TBE buffer $(89 \mathrm{mM}$ Tris, $89 \mathrm{mM}$ Boric acid, 2 $\mathrm{mM}$ EDTA) at 115 volt for $3 \mathrm{~h}$. The fragment patterns were photographed under UV light for further analysis. A $100 \mathrm{bp}$ standard DNA ladder as the molecular standard in order to confirm the appropriate markers was used for SRAP analysis.

\section{Statistical analysis}

Data of fruit fruit characters were analyzed using JMP 5.0 (SAS Institute Inc., Cary, NC, USA) and means were separated and grouped (a, ab, abc, abcd, b, . . etc.) using Tukey's test $(P<0.05)$. Molecular analysis was carried out as follows: each band was scored as present $(1)$ or absent $(0)$ and data were analyzed with the Numerical Taxonomy Multivariate Analysis System (NTSYS-pc) software package (Rohlf, 2000). A similarity matrix was constructed using SRAP data based on Dice (1945) coefficient. Then, the similarity matrix was used to construct a dendrogram using the UPGMA (unweighted-pair group method arithmetic average) to determine genetic relationships among the cultivars studied. The genetic similarity matrix and ultrametric distance matrix produced from UPGMA-based dendrogram with COPH module nested in the same software was compared using Mantel's matrix correspondence test (Mantel, 1967). The result of this test is a cophenetic correlation coefficient, $r$, that indicates how well dendrogram represents similarity data. The principal components analysis (PCA) of the original binary data matrix was also performed using NTSYS-pc version 2.1.

\section{Results and Discussion}

\section{Fruit characteristics}

There were significant differences for all fruit quality parameters except $\mathrm{pH}$, acidity and SSC/Acidity at $P<0.05$ (Table 1 ). The

Table 1. Fruit quality characters of 17 quince cultivars

\begin{tabular}{|c|c|c|c|c|c|c|c|c|}
\hline Cultivars & $\begin{array}{c}\text { Fruit weight } \\
\text { (g) }\end{array}$ & $\begin{array}{c}\text { Fruit length } \\
(\mathrm{mm})\end{array}$ & $\begin{array}{l}\text { Fruit width } \\
(\mathrm{mm})\end{array}$ & $\begin{array}{c}\text { Fruit firmness } \\
(\mathrm{kg})\end{array}$ & $\begin{array}{l}\text { SSC } \\
(\%) \\
\end{array}$ & $\mathrm{pH}$ & $\begin{array}{c}\text { Acidity } \\
(\%)\end{array}$ & SSC/Acidity \\
\hline Sekergevrek & $308 \mathrm{~g}^{*}$ & $89.6 \mathrm{f}^{*}$ & 89.0 b-d* & $6.15 \mathrm{ef}^{*}$ & $12.5 \mathrm{k}^{*}$ & $3.05^{\mathrm{ns}}$ & 1.51 & $8.3^{\mathrm{ns}}$ \\
\hline Osmancik & $381 \mathrm{e}-\mathrm{g}$ & $109.1 \mathrm{de}$ & $87.1 \mathrm{~cd}$ & $6.24 \mathrm{E}$ & $14.6 \mathrm{~b}$ & 3.05 & $1.22^{\mathrm{ns}}$ & 12.0 \\
\hline Cengelkoy & $553 \mathrm{ab}$ & $137.1 \mathrm{ab}$ & $99.2 \mathrm{a}$ & $8.17 \mathrm{~B}$ & $12.5 \mathrm{k}$ & 2.84 & 1.98 & 6.3 \\
\hline Esmel & $335 \mathrm{f}-\mathrm{g}$ & 104.6 ef & $84.8 \mathrm{~d}$ & $8.02 \mathrm{~B}$ & 13.01 & 2.98 & 1.29 & 10.0 \\
\hline Limon & 460 b-e & $127.1 \mathrm{bc}$ & 89.0 b-d & $7.97 \mathrm{~B}$ & $13.1 \mathrm{~g}$ & 2.95 & 1.30 & 10.0 \\
\hline Havran & 490 a-d & $124.8 \mathrm{~b}-\mathrm{d}$ & $95.7 \mathrm{abc}$ & 7.49 b-d & $12.8 \mathrm{j}$ & 3.05 & 1.29 & 9.9 \\
\hline Viranyadevi & 572 a & $139.2 \mathrm{ab}$ & $99.5 \mathrm{a}$ & $6.35 \mathrm{de}$ & 13.01 & 2.84 & 1.77 & 7.3 \\
\hline Bardacik & 573 a & 145.9 a & $97.5 \mathrm{ab}$ & $7.16 \mathrm{~b}-\mathrm{e}$ & $14.4 \mathrm{c}$ & 2.90 & 1.71 & 8.4 \\
\hline Tekes & 457 b-e & $129.1 \mathrm{a}-\mathrm{c}$ & 90.6 a-d & $7.62 \mathrm{bc}$ & $13.0 \mathrm{~h}$ & 3.01 & 1.41 & 9.2 \\
\hline Kalecik & 450 b-e & $138.3 \mathrm{ab}$ & 90.5 a-d & 7.26 b-e & $13.8 \mathrm{~d}$ & 2.90 & 1.36 & 10.2 \\
\hline Istanbul & $519 \mathrm{abc}$ & $130.6 \mathrm{a}-\mathrm{c}$ & $94.7 \mathrm{abc}$ & $8.05 \mathrm{~B}$ & $15.5 \mathrm{a}$ & 2.82 & 1.62 & 9.6 \\
\hline Alaycik & $436 c-f$ & $128.0 \mathrm{bc}$ & $90.5 \mathrm{a}-\mathrm{d}$ & $5.08 \mathrm{~F}$ & 12.41 & 2.98 & 1.36 & 9.1 \\
\hline Iskilip & 383 e-g & $133.2 \mathrm{a}-\mathrm{c}$ & 88.7 b-d & 8.14 B & $12.8 \mathrm{j}$ & 2.86 & 1.56 & 8.2 \\
\hline Bencikli & 469 a-e & $137.8 \mathrm{ab}$ & $92.2 \mathrm{a}-\mathrm{d}$ & $6.79 \mathrm{c}-\mathrm{e}$ & $11.3 \mathrm{n}$ & 3.03 & 1.08 & 10.5 \\
\hline Bursa & 470 a-e & $118.8 \mathrm{c}-\mathrm{d}$ & 92.3 a-d & $7.56 \mathrm{bc}$ & $13.6 \mathrm{e}$ & 2.83 & 1.56 & 8.7 \\
\hline Esme2 & 394 d-g & $129.2 \mathrm{a}-\mathrm{c}$ & $88.2 \mathrm{~cd}$ & $8.00 \mathrm{~B}$ & $13.4 \mathrm{f}$ & 3.01 & 1.34 & 10.0 \\
\hline $32 \mathrm{SO} 4$ & $88 \mathrm{~h}$ & $50.0 \mathrm{~g}$ & $63.0 \mathrm{e}$ & $11.60 \mathrm{~A}$ & $11.6 \mathrm{~m}$ & 2.96 & 0.99 & 11.7 \\
\hline
\end{tabular}

${ }^{*}$ Mean separation within columns by Tukey's multiple range test. P $\leq 0.05$. ns: nonsignificant. SSC: Soluble Solid Content 
74

Table 2. List of SRAP primer pairs, their numbers of total and polymorphic fragments, percentage of polymorphism and obtained band range (bp)

\begin{tabular}{lcccc}
\hline Primer pairs & TFN & PFN & PP (\%) & Band range (bp) \\
\hline Me2-Em3 & 4 & 1 & 25 & $170-900$ \\
Me4-Em4 & 4 & 2 & 50 & $320-650$ \\
\hline Me4-Em3 & 5 & 2 & 40 & $300-1000$ \\
Me6-Em3 & 7 & 2 & 29 & $300-1050$ \\
\hline Me7-Em3 & 6 & 2 & 33 & $300-1000$ \\
Me8-Em2 & 10 & 8 & 80 & $110-750$ \\
\hline Me6-Em2 & 9 & 6 & 67 & $100-1100$ \\
Me3-Em3 & 9 & 9 & 100 & $200-900$ \\
Me2-Em4 & 10 & 2 & 20 & $290-1100$ \\
Me5-Em4 & 5 & 1 & 20 & $150-500$ \\
\hline Me5-Em6 & 5 & 1 & 20 & $150-500$ \\
Me6-Em4 & 6 & 6 & 100 & $300-1000$ \\
Me1-Em2 & 4 & 2 & 50 & $150-700$ \\
Me5-Em1 & 3 & 1 & 33 & $350-1000$ \\
Me6-Em4 & 9 & 4 & 44 & $200-1000$ \\
Me5-Em6 & 5 & 4 & 80 & $150-490$ \\
Me4-Em1 & 8 & 6 & 75 & $180-1000$ \\
Me6-Em1 & 3 & 0 & 0 & $300-900$ \\
\hline Me8-Em8 & 3 & 2 & 67 & $120-710$ \\
Me6-Em6 & 7 & 3 & 43 & $200-850$ \\
\hline Me7-Em6 & 5 & 0 & 0 & $200-900$ \\
\hline Me4-Em9 & 3 & 1 & 33 & $150-290$ \\
\hline Me1-Em8 & 3 & 2 & 67 & $150-700$ \\
Total & 133 & 67 & - & - \\
Mean & 5.78 & 2.9 & 50 & - \\
\hline TFN: Total fragment & number; & PFN: Polymorphic fragment number; PP: \\
Poly- & & & & \\
\hline
\end{tabular}

Polymorphism percent

highest fruit weight was obtained from 'Bardacik' ( $573 \mathrm{~g}$ ) and the lowest from '32 SO 4' (88 g). '32 SO 4' also had different morphology from the other cultivars with green-reddish rind color. It was previously reported that fruit weight of some quince cultivars ranged from $196.3 \mathrm{~g}$ ('Altin Ayva') to $461.62 \mathrm{~g}$ ('Bardacik') (Kuden et al., 2006). In our study, 'Bardacik' had the highest fruit length $(145.9 \mathrm{~mm})$, and 'Viranyadevi' had the highest fruit width (99.5 $\mathrm{mm}$ ). Similarly Dumanoglu et al. (2009) determined differences in fruit weight $(269.4-409.6 \mathrm{~g})$, lenght $(92.9-117.1 \mathrm{~mm})$ and diameter (77.3-88.3 mm) among 'Kalecik' quince clones in Turkey. Fruit firmness provides information about the fruit postharvest quality. In our study, the highest fruit firmness value was determined in ' $32 \mathrm{SO}$ $4\left(11.60 \mathrm{~kg} / \mathrm{cm}^{2}\right)$, whereas the lowest in 'Ekmek' $\left(5.08 \mathrm{~kg} / \mathrm{cm}^{2}\right)$. SSC was the highest in 'Istanbul' (15.5\%), wheras it was the lowest in 'Bencikli' (11.3\%). There were no statistically differences among the cultivars for acidity and SSC/Acidity ratio. The highest SSC/Acidity ratio was obtained from 'Osmancik'(12.0\%). This trait give knowledge about fruit flesh taste whatever sourish or sweet. Also, Sykes (1971) reported fruit weight was $322 \mathrm{~g}$ for 'Bencikli', $183 \mathrm{~g}$ for 'Midilli', $290 \mathrm{~g}$ for 'Esme', $815 \mathrm{~g}$ for 'Havran' $365 \mathrm{~g}$ for 'Sekergevrek' and $245 \mathrm{~g}$ for 'Istanbul'. Kuden et al. (2006) carried out a study in Turkey to determine some qualitative traits of promising quince types which were selected in different regions. They used 'Kalecik' (0612), 'Ekmek' (2604 and 2609), 'Cengelköy' (2601), 'Seker' (3403), 'Limon' (0514), 'Bardacik' (3704), 'Altin Ayva' (3401), 'Tekkes' (0156), 'Istanbul' (0518), 'Yerli' (1918) and 'Esme' (5401 and 5403) as plant material. Some pomological traits, amounts of tannins and difficulty of swallow traits of these quince types were determined. According to their results, the largest fruits were obtained from 'Bardacik', 'Istanbul', 'Limon' and 'Seker' quince types respectively and the smallest fruits were obtained from 'Altin Ayva'.
'Bardacik' had the biggest fruits also in our study. On the other hand, difficulty of swallow traits was least in Seker, Limon, Tekkes and Esme (5401) quince types respectively and the highest difficulty of swallow trait was obtained from 'Cengelköy'. There were some differences for fruit traits among reported study and our present study because of different evaluation conditions.

\section{Molecular analysis}

Seventeen quince cultivars were evaluated by SRAP markers. A total of 133 bands were evaluated from the 23 SRAP primer combinations and 67 of them were polymorphic ( $50 \%$ of polymorphism ratio). Number of bands per primer combinations was 5.78 whereas polymorphic bands per primer combinations was 2.9. Me3-Em-3 and Me8-Em-2 had the highest number of polymorphic bands ( 9 and 8 ). The lowest number of polymorphic bands was obtained from Me2-Em3, Me5-Em4, Me5-Em6, Me5Em1 and Me4Em9 combinations. The highest polymorphism ratio (100\%) was found in Me3-Em3 and Me6-Em4 primer combinations. All bands produced by Me7-Em6 primer combination were monomorphic (Table 2). Previously some primer combinations seem to be more efficient than others in producing stable and reproducible DNA fingerprints (This et al., 1997). Cophenetic correlation between ultrametric similarities of tree and similarity matrix was found to be high $(r=0.98, P<0.01)$ suggesting that the cluster analysis strongly represents the similarity matrix.

Genetic similarities of 17 quinces ranged between 0.78-1.00 (Fig. 1). Genetic variation among cultivar was low except ' $32 \mathrm{SO} 4$ ' and 'Sekergevrek'. '32 SO 4' which was the most distinct cultivar from the others with 0.78 of similarity ratio. This accession might be distinguished with its green-red rind color. It was selected from commercial orchard by researchers from Fruit Research Station Egirdir, Isparta, Turkey. Also it had the smallest fruit in our study. The rest of 16 quince cultivars divided in two groups. One group consistent of only one cultivar 'Sekergevrek'. Fifteen cultivars nested in second group. In this group, 'Esme-2' clearly separated from the others. Genetic similarity of fourteen cultivars was over 0.95 . 'Osmancik' and 'Cengelkoy' belongs to same subgroup. In the other subgroup 'Bursa' separated clearly whereas other 11 cultivars nested closely related. 'Esme 1' and 'Tekes' were similar. We used two 'Esme' cultivar in our study and they were not similar genetically. Probably 'Esme' name may be a mixed population instead of one cultivar. Sanchez et al., (1988) reported that 'Tekes' and 'Limon' cultivars had same isozyme pattern. In our study, this two cultivars were also closely related. Yamamoto et al., (2004) identified quince varietes and rootstocks using SSR markers. They found 0.67-1.00 genetic similarity among 20 accessions. Consistent with our study, some quince cultivars were similar and genetic similarity was over 0.95 according to SSR study. In the present study, some of quince cultivars were separated within small binary subgroups such as 'Havran' and 'Istanbul'; 'Kalecik and 'Alaycik' and 'Bardacik' and 'Bencikli'.

Dumanoglu et al. (2009) assessed uniformity within a quince cultivar 'Kalecik'. They evaluated fruit traits of six different clones within 'Kalecik' quince plantations over a 2-years of period. Additionally, they performed genetic analysis in clones with seven SSR (microsatellite) loci. According to their important fruit characteristics, Clone 6 was selected as the best in both years. SSR analyses revealed that Clone 4 was genetically distant from other clones. They found that 'Esme' was distinct from 'Kalecik' quince clones. In our SRAP data 'Kalecik' nested in separate subgroup from 'Esme' cultivars which consistent with their SSR data. On the other 
hand Bayazit et al. (2011) also assumed for RAPD data 'Kalecik' and 'Esme' cultivars apart from each other.

The principal components analysis (PCA) was performed for better visualisation of relations among the accessions studied. The classical principal components analysis is likely an example of dimensionality reduction. Therefore it is important that the required information is strongly related to the variance in the data (Scholz and Selbig, 2006). The PCA revealed some aspects of interrelations among the studied materials that were not discernable by the cluster analysis (Marak and Laskar, 2010). The results of PCA are demonstrated in Fig. 2. PCA-1 and PCA-2 represented $92.8 \%$ and $2.4 \%$ of the variation in the binary data matrix, respectively. It implies that $95.2 \%$ of the total variation in the original dimensions could be represented by just two dimensions defined by the first two PCs. Two-dimensional dispersion showed that some quince cultivar clearly separated on the dispersion graphic. '32 SO 4' and 'Sekergevrek' were distinct from others. 'Esme-2', 'Bursa',
'Osmancik' and 'Cengelkoy' also distinguished. The rest of 11 cultivars constituted an intensive group. It can be concluded that, genetic diversity among this group was low consistent with our dendrogram.

In our study, SRAP markers firstly used in quince with this study and showed that it can be used for characterization and diversity analyses of quince genetic resources. We obtained polymorphism by using SRAP markers and this system can be used for cultivar identification in quince. The findings from SRAP analysis showed that although there were polymorphism among quince cultivars, it was not consistent with geographical origin and also there was no correlation between molecular and morphological data of the studied set of quince accessions

In Turkey, quince also has been used as rootstock for pear and fruit production for a long time almost in all regions, mostly in Aegean, Marmara and Central Northern of Turkey. Different quince genotypes are grown in these regions and named different

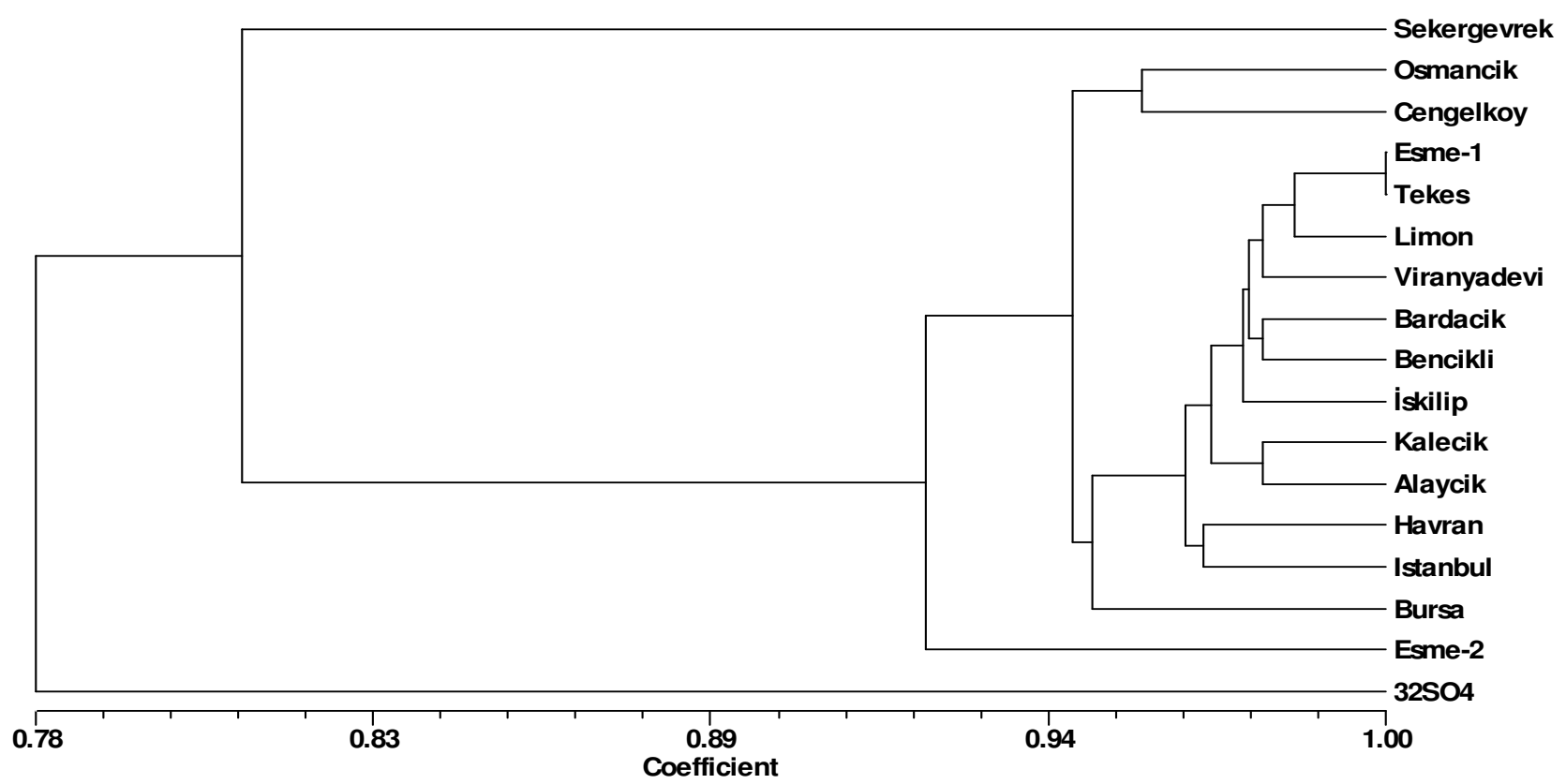

Fig. 1. UPGMA dendrogram of quince (Cydonia oblonga Mill.) accessions based on 23 SRAP primer combinations

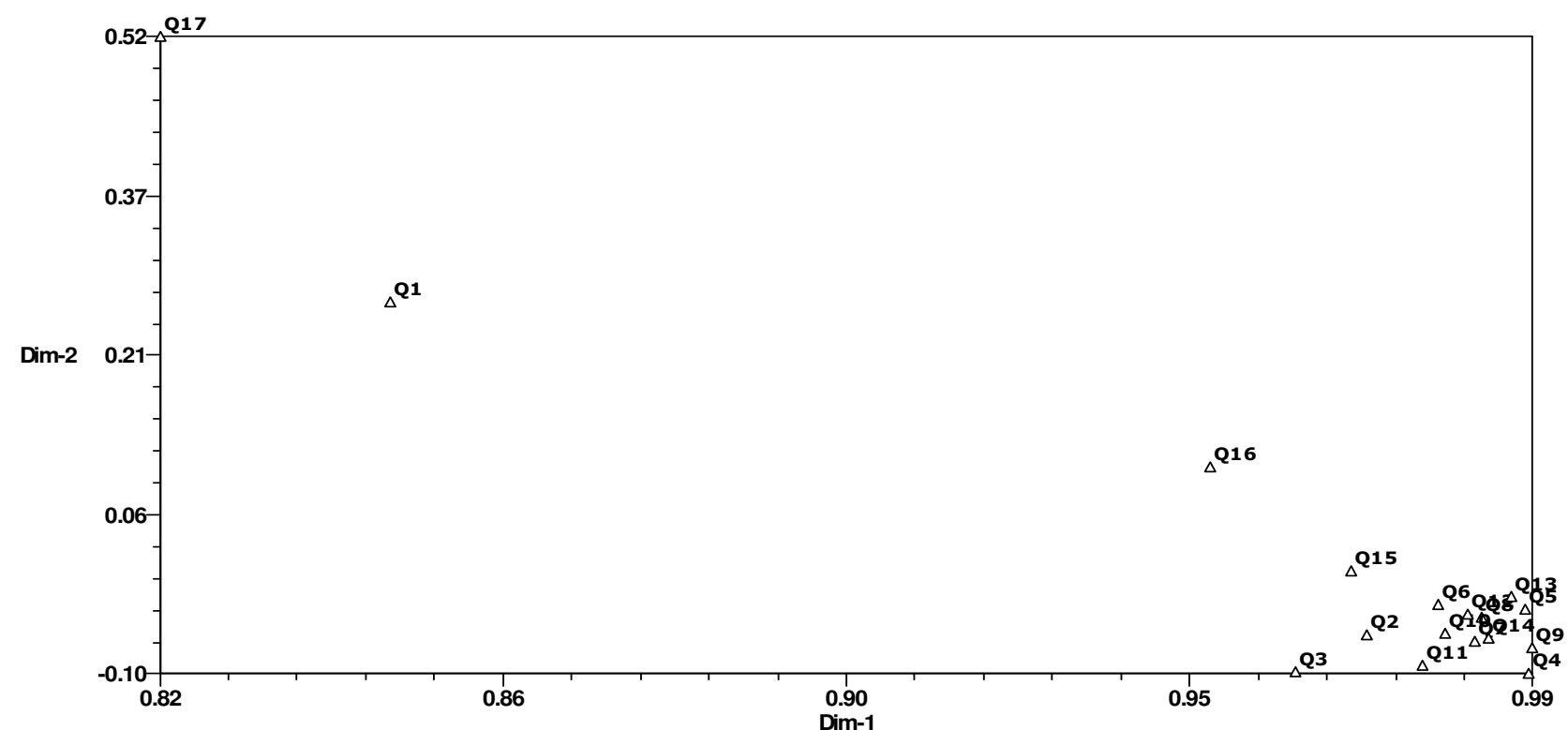

Fig. 2. Two-dimensional plot of the principal components analysis of SRAP data includes quince cultivars 
76

synonyms at different locations. There are some studies for clonal selection and conservation of genetic materials. These genetic materials were preserved at some centers which located in different regions of Turkey. But there are confusion to determination of cultivar or genotypes and transfer to different locations.

\section{Conclusion}

Determination of variation is very important among quince cultivars for breeding programs and orchard management. Identification of quince genotypes using only pomological and phenological data is difficult. Use of molecular markers is the best solution for identification accessions at early stage. In our study, SRAP system was used for the first time in quince cultivars to determine genetic variation. SRAP marker system can be used for cultivar identification and genetic diversity in quince. Results of this study regarding to fruit characters and molecular analysis may be used for conservation of genetic resources and programming future breedingstudies.

\section{References}

Bajpai PK, Warghat AR, Sharma RK, Yadav A, Thakur AK, Srivastava RB, Stobdan T (2014).Structure and genetic diversity of natural populations ofMorus alba in the Trans-Himalayan Ladakh Region. Biochemical Genetics 52(3):137-152.

Bayazit S, Imrak B, Kuden A, Gungor MK(2011). RAPD analysis of genetic relatedness among selected quince (Cydonia oblonga Mill.) accessions from different parts of Turkey. Horticultural Science 38:134-141.

Dice LR (1945). Measures of the amount of ecologic association between species. Ecology 26:297-302.

Doyle JJ, Doyle JL (1990). A rapid total DNA preparation procedure for fresh plant tissue. Focus 12:13-15.

Dumanoglu H, Gunes NT (2009). Analysis of clonal variations in cultivated quince (Cydonia oblonga 'Kalecik') based on fruit characteristics and SSR markers. New Zealand Journal of Crop and Horticultural Science 37:113-120.

Erayman M, İlhan E, Güzel Y, Eren AH (2014). Transferability of SSR markers from distantly related legumes to Glycyrrbiza species. Turkish Journal of Agriculture and Forestry 38:32-38.

Ercisli S (2004). A short review of the fruit germplasm resources of Turkey. Genetic Resources and Crop Evolution 51:419 435.

$\mathrm{FAO}(2012)$.http://faostat.fao.org/site/567/DesktopDefault.aspx?PagelD=56 7\#ancor (accessed April 5, 2015).

Feng SG, Lu JJ, Gao L, Liu JJ, Wang HZ (2014). Molecular phylogeny analysis and species identification ofDendrobium (Orchidaceae) in China. Biochemical Genetics 52(3):127-136.

Ferriol M, Pico B, Nuez F (2003). Genetic diversity of a germplasm collection of Cucurbita pepo using SRAP and AFLP markers. Theoretical and Applied Genetics 107:271-282.

Gulsen O, Shearman RC, Vogel KP, Lee DJ, Baenziger PS, Heng-Moss TM, Budak H (2005). Nuclear genome diversity and relationships among naturally occurring buffalograss genotypes determined by SRAP markers. HortScience 40:537-541.

Halasz J, Hoffmann V, Szabo Z, Nyeki J, Szabo T, Hegedus A (2009). Characterization of quince (Cydonia oblonga Mill.) cultivars using SSR markers developed for apple. International Journal of Horticultural
Science 15:7-10.

KaçarY,Şimşsek O, Dönmez D, Boncuk M, Yeşiloğlu T, Ollitrault P (2014). Genetic relationships of some citrus genotypes based on the candidate iron chlorosis genes. Turkish Journal of Agriculture and Forestry 38:340-347.

Kuden A, Tumer MA, Gungor MK, Imrak B (2009). Pomological traits of some selected quince types. Acta Horticulturae 818:73-76.

LiG, Quiros CF (2001). Sequence-related amplified polymorphism (SRAP) a new marker system based on a simple PCR reaction: its application to mapping and gene tagging in Brassica. Theoretical and Applied Genetics 103:455-461.

Mantel N (1967). The detection of disease clustering and a generalized regression approach. Cancer Research 27:209-220.

Marak CK, Laskar MA (2010). Analysis of phenetic relationship between Citrus indica Tanaka and a few commercially important citrus species by ISSR markers. Scientia Horticulturae 124:345-348.

Rodger CE, Campbell CS (2002). The origin of the apple subfamily (Maloideae; Rosaceae) is clarified by DNA sequence data from duplicated GBSSI genes. American Journal of Botany 89:1478-1484.

Rohlf FJ (2000). NTSYS-pc, Numerical Taxonomy and Multivariate Analysis System. Version 2.11. New York, Exeter, Setauket.

Ruttanaprasert R, BanterngP, JogloyS, Vorasoot N, Kesmala T, Kanwar RS, Holbrook CC, Patanothai A (2014). Genotypic variability for tuber yield, biomass, and drought tolerance in Jerusalem artichoke germplasm. Turkish Journal of Agriculture and Forestry 38:570-580.

Sanchez EE, Menendez RA, Daley LS, Boone RB, Jahn OL, Lombard PB (1988). Characterization of quince (Cydonia) cultivars using polyacrylamide gel electrophoresis. Journal of Environmental Horticulture 6:53-59.

Scholz M, Selbig J (2006). Visualization and analysis of molecular data. In: Weckwerth W (Ed). Metabolomics: Methods and Protocols. Methods in Molecular Biology, Vol 358. Humana Press, New Yorkpp 87-104.

Sharma R, Joshi VK, Rana JC (2011). Nutritional composition and processed products of Quince (Cydonia oblonga Mill.). Indian Journal of Natural Products and Resources 2:354357.

Sykes JT (1972). A description of some quince cultivars from western Turkey.Economic Botany 26:21-31.

This P, Cuisset C, Boursiquot JM (1997). Development of stable RAPD markers for the identification of grapevine rootstocks and the analysis of genetic relationships. American Journal of Enology Viticulture 48:492501.

Uzun A, Yesiloglu T, Aka-Kacar Y, Tuzcu O, Gulsen O (2009). Genetic diversity and relationships within Citrus and related genera based on sequence related amplified polymorphism markers (SRAPs). Scientia Horticulturae 121:306-312.

Uzun A, Gulsen O, Seday U, Bircan M, Yilmaz KU (2010). SRAP based genetic analysis of some apricot cultivars. Romanian Biotechnological Letters 15:5396-5404.

Westwood MN (1993). Temperate-Zone Pomology Physiology and Culture. 3rd ed. Portland, Oregon, Timber Press Inc.

Yamamoto T, Kimura T, Soejima J, Sanada T, Ban Y, Hayashi T (2004). Identification of quince varieties using SSR markers developed from pear and apple. Breeding Science 54:239-244. 